\title{
The Role of Christian Education Among Religious and Pluralism Society at the Post Truth Era
}

\author{
Deflita R. N. Lumi ${ }^{1}$, Berdinata Massang² \\ Christian Education Faculty of IAKN Manado, Bougenville Street, \\ Tateli 1 Mandolang, Minahasa, North Sulawesi \\ deflita.stakn@gmail.com¹, berdinatamassang@iakn-manado.ac.id²
}

\begin{abstract}
This paper issue is about Christian Education which is very important to face the Post Truth Era among religious society. Post truth era can be seen based on individual knowledge of reality and individual perspective. the advanced of technology and social media uses shows the main role to evolve society in order to decide which is truth or false, hoax (twisted truth) and fake news spread among society. Hoax and fake news obviously gives impact, that's why this paper describe Christian Education role as a fence to prevent post truth era impact by critical issue method. based on issue of this paper among the society at the post truth era cause of polarization, radical, political tension, intolerant and anti pluralism, Christian educational hopefully can reduce the impact by reveal pluralism and open to the diversity, open minded and critical of receiving information based on value and moral ethic.
\end{abstract}

Keywords: Christian Education, Religious and Pluralism Society, Post Truth Era

\section{Introduction}

Indonesia is Multicultural country and that is undeniable. This can be happened because of Indonesia's vast geographical conditions. Has so many heritage, from a population consisting of various tribes, language and believe. Believes that consist of Islam, Catholic, Christian, Hindu, Buddha, Confucian and others believes.

Moeis [6] said that religious society has a vision hope to actualize multicultural societies that respect each other and able to live side by side peacefully (Democratic multicultural societies) as everyone's purpose. But the gap between reality and hope is still wide, since discover various problems such as: ethnic conflicts, both horizontal and vertical, seemed to be long-drawn.

This conflict is obvious at this globalization era by the grown usage of communication technology. Based on data of Wearesosial [12] Indonesian internet usage 56\% from population there are 150 million users also active at social media. While mobile social media user $48 \%$ from population there are 130 million users. The flare of media social usage cause of received and delivered information increasing. This received and delivered information not always valid with the truth, unfortunately this non valid information has not cross checked and instantly society consider this as the truth. This phenomenon called as post truth era.

Syuhada [9] fake is a phrase that we heard a lot lately. Like post-truth, which skyrocketed in 2016, fake-news was awarded the 2016 phrase by Collins' dictionary. In terms of fake news, fake news is an artificial news of fake news that is not based on fact, reality or truth. Hate speech is an art in legal terms and political theory, which refers to verbal behavior and symbolic action or other communicative activities deliberately express very strong anti-certain 
actions against groups and individuals (Corlett and Francescotti). The groups that arehated in this case are usually based on differences in ethnicity, religion, and sexual orientation.

Hoaxes, fake news, adan hate speech are problem nowdays, especially on social media. This problem is growing rapidly with the ability of social media to read a user's digital footprint using algorithmic system. Through this system, the traces of the status or posts they read will be recorded by social media and will suggest reading a similar status or post even though there are so many other posts. It is feared if the read post is hoaxes, fake news, and hate speech that are read repeatedly will be believed to be true an influence others, where this pattern threatens democracy.

This post truth era gain hoax, fake news, and hate speech. If we are rememorized the latest Indonesian election, hoax and fake news become a campaign media to strike down candidate. Hoax and fake news which is offend ethnic, religious, racial, and inter-group issues. Lack of literacy of Indonesian unconsciously makes hoax and fake news growth. Society will instantly share the information without recheck the validation. Incorrect perspective to candidate or certain candidate will cause of horizontal conflict or polarized among society.

As a religious society and purpose the peacefully to others, then supposed to be controlled ourselves while share the information at this post truth era. These become circumstances for religious society especially for Christian to face post truth era to keep become light and salt. Since this become the main issue of this article will answer and solved problem based Christian education.

\section{Research Method}

Critical Discourse Analysis (CDA) as research methodology has evolved politically with emancipator needs tried to give impact to social practical and social relationship, non sexist language usage guidance or propose to increase news comprehension and law text. Titscher, et all [10]. This method choosed based on comprehension that language consider as social practical shape and tried to realized that feed back between language and social structural usually not realizeable.

\section{Result and Discussion}

\subsection{Christian Education}

Christian Religious Education and Character is not just a process of conveying moral messages, simply knowing the procedures of the relationship between humans and God, but rather presenting transformative and internalized curriculum content of the Christian Religious Education curriculum might be change and renew students perspective, attitudes and direct students to understand God's calling to be a blessing for others and the world.

The function of Christian Religious Education in Government Regulation Number 55 of 2007 concerning religion education and religious education, it is stated that: religious education functions to shape Indonesian people who believe and fear God Almighty and noble character and are able to maintain peace and harmony of inter-community relations religion (article 2 paragraph 1). Furthermore, it is stated that religious education aims to develop 
students abilities in understanding, living, and practicing religious values which harmonize their mastery in science, technology, and art (article 2 paragraph 2).

\subsection{Post Truth Era}

Much information is circulating at this industrial revolution era at digital and economic revolution era impact of social life among society. Today's era which is become an issue not how society received the information but how society able to proceed received information. Believes on popular media that give the information also questionable, such as television affiliated with political issue or the owner. Common social media among society such as facebook and whatsapp also not capable to share and recheck valid news.

On 2016, Oxford [7] makes the words of post-truth as "Word of the Year". The usage of Post - Truth on year 2016 increasing 2000\% compared with 2015. There are the reason why post-truth curve higher rapidly on 2016. Mostly the usage of this word almost put on two influences political moments on 2016 there are England exit from Uni Eropa (Brexit) also Donald Trump won asUnited States President.

Oxford dictionary has definition of post-truth as the condition where is the fact not gives impact to create public opinion rather than emotion and personal believe. Post-truth condition increasing at the political moment moves by the emotional sentimental like Brexit and chosen of Trump. At this situation hoax information has a great impact rather than the actual truth. Besides marked by hoax spread on social media, post-truth era also marked by doubtful media and journalism while face the fake statement from the politician. American president election 2016 as the evidence that media spread fake news related with Donald Trump, becomes make Trump more popular and the lies spread rapidly.

Based on Oxford Dictionary post-truth firstly used on 1992 by Steve Tesich that used posttruth at The Nation magazine when reflection of Gulf War and Iran case that happened at this period. Tesich highlighting that "we are as the free human, has the freedom determined that we want to live at post-truth world". While Ralph Keyes [3] on his book The Post-truth Eraand comedian Stephen Colber also makes the word related with post-truth popular that is truthiness seems like some things right even that is not right at all. Al Rodhanon Setiawan [8] said that the main characteristic of post-truth politic are:

a) Shuffle the society with the emotion issues

b) Ignore the data and fact

c) Makes viral uncertain or fake information

d) Combining popular movement by conspiracy theory that still needs validate of the truth

e) Fictive narration mobilization about certain even or figure

f) Polish unhonesty while rebuild the opinion to make the position steady of social figure, group or certain purpose among society who has get used to televisual, online, android and social media.

\subsection{Religious Society}

WachdalamUlya [11] defined religious or diversity with the word of religion experiences, consists of 4 (four) criteria, there are: first, response on the internalized as the solid reality. Second, this response involve holistic in activity, not only mind, sense or free will, but total potential and human ability. Third, there is certain depth, forth, the expression of this experience in verb include thought, act and grouping live. 
Religious society is the societies that believe one value and system that legitimated that centralized the power outside the human itself. Totally needs to comprehens religious dimension. According to Glock dan Stark [1] consists five dimensionsreligiousitythere are, ideologies dimension (the ideological dimensions/religious belief), ritualisticreligion dimension (the ritualistic dimensions/religious practice), eksperiencialand centralizeddimension (the experimentation dimensions/ religious feeling), intellectualreligion dimension (the intellectual dimensions / religious knowledge), andconsequential dimension (the consequential dimensions / religious effect).

First, The ideological dimensions /religious belief) is the hopes where the religious hold on certain theologies and admit the truth of Christian doctrines involves cognitive process. Second, the ritualistic dimensions/ religious practice kind of worship, obedience, and the acts that people do to shows commitment to their faith of religion and this dimension is conative issue that refers to obedience. Third, the experimental dimensions / religious feeling is the dimension that correlate with religion comprehens, feelings, perceptions, sensations that someone's felt or defined by some group of religion (or society) that consider communication to God presence even in a small condition. Fourth, the intellectual dimensions / religious knowledge refers to every believer at least has a basic knowledge of faith, hope, holy bible, tradition that include cognitive process that refers to society knowledge and comprehens to the main doctrine, such as Bible contains, Christian obligation and religion ceremonies. The consequential dimensions / religious effect refers to someonesbehaviour according to their religion motivates, how they can interpretated doctrine in daily life that the others contemplative issue, that shows students daily behavior motivated by their religion.

\subsection{Christian Education Among Pluralism Society}

Christian religion is the conscious act and well prepare to put Jesus Christ in Christian faith growness by makes the learning and teaching process actively and develop their potential to have spirit power by control themselves, personality, intelligence, good manners also skill that might be their or society needs.

Christian society stays and lived at plural environment. The plural include religion, culture, church, social class and grouping. Because of it, the touch of faith direct or indirect will have impact. That touch may start from formal or non-formal education or environment influences. These things become intern-extern conflict source. To prevent these not happen in Indonesia, the religion comprehens needs to be given in order for peacefully and to avoid conflict. Hope to enrich the faith, create peaceful among diversity in society of Indonesia. That's why Christian education is really important given to society Harianto [2].

\subsection{Pluralism Context}

Pluralism in The Oxford English Dictionary defined as, first theory that against monolithic rules; oppositely decentralization support and autonomy for some main organization that representatives individualism in society. Pluralism also believes that power is shared with some politic party. Second, tolerance and exists of various ethnic or cultural group in society or nation also several of believe or act of bearou, foundation and so on. According to social dicipline pluralism is the guidance where several group shows respect and tolerance. They are lives together and gain assimilation without conflict.

Pluralism at this nation especially religion pluralism is unbreakable truth. That's why Pancasila has choosen by the founding father as the Nation root in order to united the diversity 
among society to be tolerant, honor the religion and respect diversity include religion pluralism.

\subsection{Problematic Context}

At the other hand religion in Indonesia reflect the beauty and variety in Indonesia, pluralism makes every person learn and see the differences among others. Interrelation various religion and faith might be happen. Besides religion pluralism not always good means tension and conflict might still happen.

Media and Internet usage at post-truth era increase the tension and conflict among religious society and pluralism. One of the big even that happen in Indonesia related with the internet usage has been tested and massive. Not all online information are truth. there is also false, incorrect, lies and without valid sources.

Mahzumi [5] is era when the freedom has the field at social media and internet. Everyone is free to download and share any information without any sort or surveilence. That's why fact and fiction combined, between science and pseudo unsortable. This condition looks like knife that has to sides helpful and dangerous up to the user and sharp uses. Online information users are having solid power if not critical or selective will be stuck at the pool of lies and legacy the unstable future generation. Due of this dilemma its difficult to act from one great achievement such as internet. If too defensive then will cause of primitive society at this high technology age, oppositely if too offensive then will cause post-truth society because don't have ability to sort the truth.

This primitive society at the high technology age and post-truth becomes our nation task against hoax, lies and fake news. Christian education also has a role of this. Christian education has responsibilities to makes society to be offensive and able to survive among the pluralism society by the loves of each others.

\subsection{Fundamental Curriculum}

Christian education gives the teacher responsibilities related with experience of the student to create from the experience and knowledge can be a reflection. This experience share and reflected with others to gain the wisdom as the live guidance. The teacher's experiences well shared and can be contributed to gain the information process, formation and transportation.

While certification this perspective Lois LeBar[4] said very helpful in the refers to education wisdom that has by John Amos Comenius and progressive education movement United States include John Dewey (1859-1952). LeBar said Christian content without experience are nonsense and experience without content are blind. The challenge for curriculum maker is combining either Christian content and experience and makes the students thought and live will fulfill and changed by the God's truth.

Effective curriculum combining content and Christian experience the impact of this curriculum will transform live. This potential needs active participation form the person who has effort to learn and welcome the pluralism and accept that diversity as the grace from God.

There is none simple formula can combine content and experience evenly but there is guidance. Teacher called to have education and have sense of content dimension from various students experience of their own context. Based on sense and knowledge teacher can adopt the suitable material for the students. This combination can implicate that we need to give attention to the love and truth in Christ perspective also sense to show Christian moral as the role model. 
That's why the Christian education at the school as the strategic tools to create the faith literally. Especially to face the pluralism at the Indonesia society. Christian education should have to make Christian student become the offensive person and able to live among pluralism society, religion, race or group. While use mass media and IT and communication we should find the truth firstly. Sincere love to earn correct information. Since we are the big nation so we are need to be a peace maker among differences from intolerant, racist and radicalism and cause separated.

Christian Education has to make decisions that directly affect the actual practice of education. These decisions are specifically concerned with planning, implementing, and evaluating a curriculum. Christian educator can explore the foundations of the curriculum by focusing on the concrete relations that occur in the midst of a special society in live in diversity.

\subsection{The Importance of Media Literacy}

The existence of fake news at post truth era among the religious and pluralism society mostly influenced by social media. Social media easily spread the fake news and hoax. We don't need to gather people at certain point and do rendezvous conventionally. By social media we can access news everywhere and anywhere even if the writer unknown or anonym can be consider the truth only based on same perspective between the writer and society.

The key to control ourselves at the post-truth era by practice and increase our literature ability to understand massive information at post truth era. Many lies news seems like make the correct perception because the weakness of someone literaty. There are so many ways to seek the truth especially at this digital era.

Christian education also needs to appoint the importance of media literacy. Strategic purpose to make peaceful society among pluralism society can be held eventough there are some misperception. Due the society perspective about religion has an impact to receive information include the Christian religion information by the depth of ourself based on ability to comprehens, analyze and deconstruction media image. Hope by this method while someone touch with internet they are know about the access information so not become the person who has not ability or can easily influenced. The "Media aware" already start at the several location in Indonesia with various approach either culture or academy. The lie has a same age with human history. To erase the hoax by this way totally is not easy. As we all know well there are still has an advantage either individual or group still continuous "lie" conserving purpose,Mahzumi [5].

\section{Conclusion}

As a country with such cultural diversity and religious differences that Indonesia society is a pluralism and religious society. But in our nation and citizen lives, facing the problem of the post truth era, in spreading information that is not always true, but is a hoax and fake news on social media. There needs to be solution to this problem, especially for the Christian society, a role of Christian education in order for the society to adopt a Christian sense of morality to exemplify. Set the ultimate example in the use of social media by the immersion of abilities in internet users to understand, analyze, and deconstruct media imaging. 


\section{References}

[1] Glock, C. Y., \& Stark, R. (1965)Religion and Society in Tension. Chicago: Rand McNally.

[2] Harianto. (2012) Pendidikan Agama Kristen dalamAlkitab dan Dunia Pendidikan Masa Kini. Yogyakarta: Andi.

[3] Keyes, Ralph.(2004) The Post-Truth Era Dishonesty and Deception in Contemporary Life. St. Martin's Press.

[4] Lebar, E. Lois. (2006). Education That is Christian. Malang: Gandum Mas.

[5] Mahzumi, Fikri. (2017) Hoax, NestapaKebohongan Era Post-Truth. Al- Fikrah, 98 (1), 29-34

[6] Moeis, Isnarmi. (2014).Pendidikan MultikulturalTransformatif, Integritas Moral, Dialogis, dan Adil. Padang: UNP Pres.

[7] Oxford. (2016). "Word of the Year 2016 is..." (On-line), Oxford Dictionaries. Accessed November 27, $2019 \mathrm{https} / /$ languages.oup.com/word-of-the-year/word-of-the-year-2016

[8] Setiawan, Ikwan. (2017). Media Sosial, Politik Post-Truth, dan TantanganKebangsaan, Matatimoer Institute.

[9] Yuhada, D, Kharisma. (2017). Etika Media di Era "Post-Truth". JurnalKomunikasi Indonesia, 5 (1), 75-79.

[10] Titscher, dkk. (2009). MetodeAnalisis Teks dan Wacana. Yogyakarta: Pustaka Pelajar

[11] Ulya. (2018). Post-Truth, Hoax, dan Religiusitas di Media Sosial. Fikrah: JurnalllmuAkidah dan StudiKeagaamaan, 6 (2), 283-302.

[12] Wearesosial, Hootsuite. (2019). “BerapaPengguna Media Sosial Indonesia?" (On-line),
Databoks
Accessed
November
27
2019 https://databoks.katadata.co.id/datapublish/2019/02/08/berapa-pengguna-media-sosial-indonesia 